\title{
ESSENTIAL CHARACTERISTICS OF NAVAL LITTORAL DOCTRINE
}

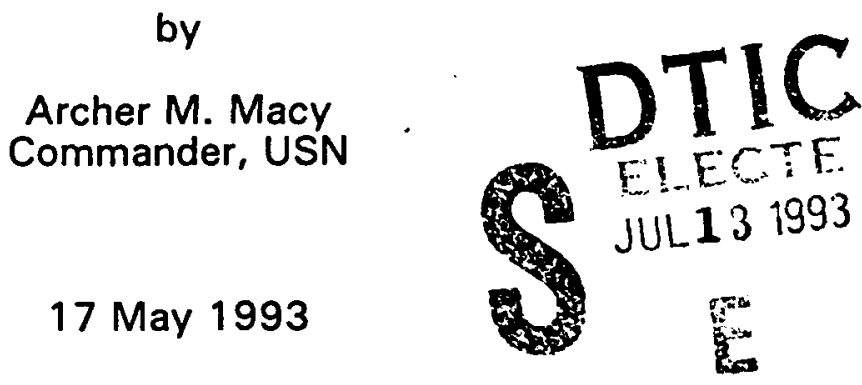

A paper submitted to the Faculty of the Naval War College in partial satisfaction of the requirements of the Department of Operations.

The contents of this paper reflect my own personal views and are not necessarily endorsed by the Naval War College or the Department of the Navy.
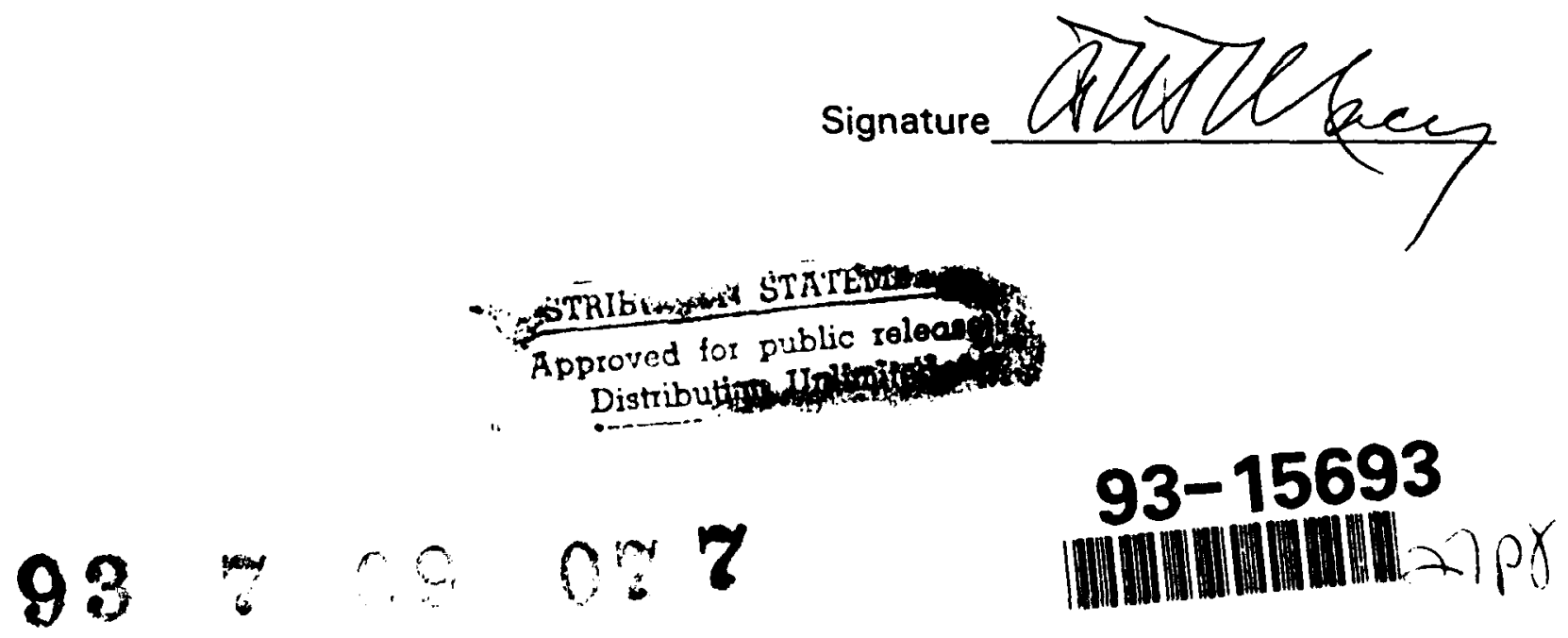


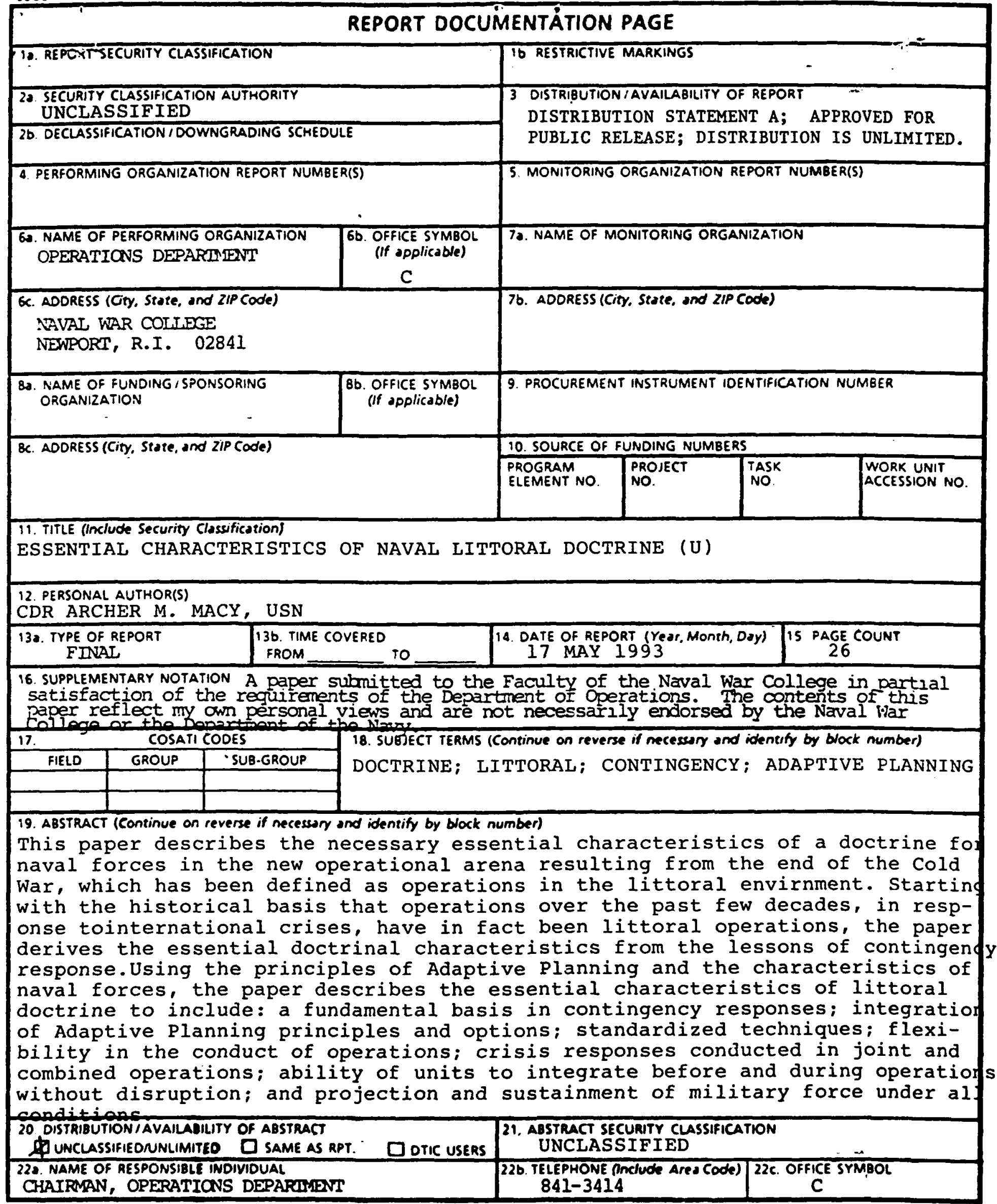

DO FORM 1473, 84 MAR 83 APR edition may be used untl exhausted. All other editions are obsolete

0102-LF-014-6602
SECURITY CLASSIFICATION OF THIS PAGE

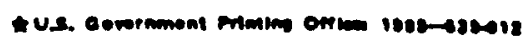




\section{Abstract}

This paper describes the necessary essential characteristics of a doctrine for naval forces in the new operational arena resulting from the end of the Cold War, which has been defined as operations in the littoral environment. Starting with the historical basis that operations over the past few decades, in response to international crises, have in fact been littoral operations, the paper derives the essential doctrinal characteristics from the lessons of contingency response. Using the principles of Adaptive Planning and the characteristics of naval forces, the paper describes the essential characteristics of littoral doctrine to include: a fundamental basis in contingency responses; integration of Adaptive Planning principles and; standardized techniques; flexibility in the conduct of operations; crisis responses conducted in joint and combined operations; ability of units to integrate before and during operations without disruption; and projection and sustainment of military force under all conditions.

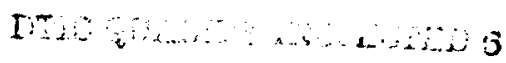

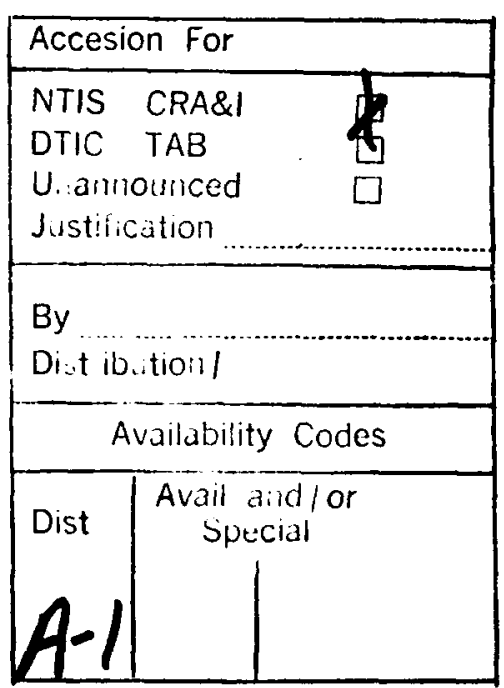




\section{Introduction}

"We must remember that where we place our naval forces is every bit as important as what we place there. It is not enough to have adequate capability: it must exist in the right numbers, and we must have the ability to employ it." (emphasis added) ${ }^{1}$

This observation by a combatant commander describes a fundamental problem of naval planning, which has grown ever more difficult to satisfactorily address in an era of reduced assets and operating budget. Compounded by an increased volatility in international affairs, the challenge for naval forces in the future will be to cover a greater range of operational commitments, with fewer assets, and with a shorter response time in a given situation. In order to satisfy these apparently conflicting demands, naval forces must be able respond on short notice, with the assets available, and already in possession of the necessary essential planning and execution skills.

This paper proposes the essential characteristics of an operational doctrine which will serve as the basic framework for naval forces to meet these new challenges. This work is based upon the new military and naval strategy that emphasizes littoral operations, and is drawn from the recent explosion of ideas and professional discussions that have accompanied the end of the Cold War; the lessons learned from naval operations over the past decade; and a variety of predictions for the future employment of naval forces in protecting US national interests.

1 Charles R, Larsen, "National Interests and Naval Forces in the 1990s," Naval War College Review (Winter 1990): 16. 


\section{Littoral Operations}

The new official emphasis of naval operations is described as the littoral region, which is defined as the "near land areas of the world." 2 This description includes the water "area from the open ocean to the shore which must be controlled to support operations ashore", and the land "area inland from shore that can be supported and defended directly from the sea." 3 What this description accomplishes, along with re-focusing naval planning from the blue water battle to the brown water conflict, is to mandate significant changes in the capabilities that individual, smaller naval forces must possess to succeed in executing assigned tasks.

Of note is the fact that the majority of naval operations over the past 50 years have, in fact, been littoral operations. While the U.S. Navy spent a great deal of time, money and effort in preparing for open ocean conflict against the Soviet Union, encapsulated in the old Maritime Strategy4, the Navy's actual employment has been in littoral operations. Vietnam, Panama, Granada, EI Dorado Canyon, Earnest Will, Praying Mantis, and Desert Shield/Storm all

2 Sean O'Keefe, Frank B. Kelso II, and Carl E. Mundy, Jr., ...From the Sea. Navy and Marine Corps White Paper, Department of the Navy, Washington, D.C., September 1992, 5.

3 Ibid., 5.

4 Stephen D. Schmidt, "A Call for an Official Naval Doctrine," Naval War College Review (Winter 1993), $48 f$. 
involved significant operations in the littoral environment. The U.S. Navy has not fought a major engagement at sea since Leyte Gulf.

The Maritime Strategy was predicated on a fairly rigid description of threat and set of mission requirements: defeat the Soviet Navy and ensure the integrity of the logistic pipeline from North America to Europe. This relatively narrow scope provided a basis on which U.S. Navy capabilities were built; this in turn defined the tactics, training, structure and equipping of the Navy. The new era of littoral warfare, encompassing a wide possibility of different regional conflicts and tensions, removes the assurance that the Maritime Strategy provided and demands greater flexibility on the part of naval forces, where ever and when ever they are placed around the world.

This provides a distinct change in the management of planning for the employment of naval forces. Prior to the collapse of the Soviet Union, the longterm effort of strategic concept development and detailed response planning was concentrated on the global war threat, while actual operations in crisis were, perforce, conducted on a mostly ad hoc basis. With the disintegration of our major adversary and the concomitant reduction in the need to plan for conflict in the global arena, naval force leadership is afforded the opportunity to devote heretofore unavailable time and resources to better preparing for contingency, and thus historically littoral, operations.

While this observation offers some promise for the transition to the new strategy of "From The Sea", it is countered by the observation that the Navy is, 
with the end of the Cold War, shrinking in both size and budget. What this means is that the flexibility to provide forces to meet operational requirements in any region is also reduced. Where in the past the Navy was large enough to meet tasking with units trained and tailored for each task, the Navy of the next decade will have to meet the same requirements with fewer units, each of which possesses a greater range of capabilities ${ }^{5}$. Instead of having ten different specialists available to do ten different tasks, the Navy will have to have three generalists each capable of doing many different tasks.

The other characteristic of future naval operations will be their contingent nature: "...the highest probability for U.S. military involvement is related to regional issues where conflict could arise as a result of regional instabilities that involve fundamental American interests" 6 . One study noted that naval forces had responded in four out of every five crises where military forces were used in the last 45 years 7 , while a separate review showed that approximately seventy percent of those involved operations on, over, or near the land mass of another nation. 8

5 H. Lawrence Garrett, III, Frank B. Kelso II and A. M. Gray, "The Way Ahead," Proceedings (April 1991), $41 \mathrm{f}$.

6 Department of the Navy, The Necessity for Naval Power in the 1990s, OP-08 White Paper, (Washington, D.C., 1989), 5.

7 Barry M. Blechman and Stephen S. Kaplan, The Use of Armed Forces as a Political Instrument, (Washington, D.C.: Brookings Institution, 1977), 5.

8 Barry M. Blechman, "Global Power Projection - The U.S. Approach," in Projection of Power: Perspectives. Perceptions and Problems, ed. Uri Ra'anan, 
What the preceding review of naval focus and historical employment suggests is that littoral operations have, and will be, primarily contingency operations, and, that the naval forces will be the primary response in such operations in the future. This leads to the inescapable conclusion that any doctrine for littoral operations will have to be based primarily on the principles of contingency response.

\section{Characteristics of Contingency Operations}

As previously noted, US naval forces have conducted the majority of their operations over the last several decades as contingency operations; i.e., generally unexpected situations where the use of military force to resolve a crisis was decided upon and executed in the press of hurried events. The Marine Corps best defines contingency operations as:

"Contingencies are crisis situations, often with complex political ramifications, involving imminent or actual military conflict at the low- to mid-range of the intensity scale. These crises present a definite threat to US interests; but the situation, military mission, and military threat are often vague and uncertain. They require the analyses of diverse operational options with intervention by conventional US military forces as a major consideration. ${ }^{9}$

Robert L. Pfaltzgraff, Jr. and Geoffrey Kemp (Boston: The Fletcher School of Law and Diplomacy of Tufts University, 1992), 183.

9 U.S. Marine Corps, Corps Operations, FM 100-15 (Washington, D.C., 1988), 8-0. 
This manual goes on to summarize 10 the characteristics of contingency situations as including the following key elements:

a. US Interests are at stake.

b. There is pressure for a quick, clear victory when military force is used.

c. In general, the crisis will have an uncertain mission, political and military situation, and defined enemy, at least until the last minute prior to executing a military option.

d. Due to the highly political nature of most crises, there will be a strong tendency for centralized, high level control of the operation.

e. Time and distance requirements will constrain lift capability, thus restricting the forces available to carry out the military option.

\section{Timeliness of Response}

"Although such crises may evolve over a period of time, the decision to refine and execute the military option is usually made under timesensitive conditions. Once the decision is made to commit military forces, there is pressure for a quick, clear victory. Due to the short time between decision and execution, necessary airlift and sealift are often constrained." 11

This observation, based on both long standing and recent experience, illustrates yet another constraint on any doctrine which is to address contingency, and therefore, littoral operations. Contingency operations in the littoral environment, as well as elsewhere, will be conducted on a compressed

10 lbid.

11 lbid. 
basis, with minimum opportunity for detailed preparation, and with a minimum of "ideal" forces available. Commanders executing such operations must, therefore, be able to plan the operation, assemble forces, task-organize their assets, and execute a viable plan with the force capabilities resident in the immediate area or deliverable on very short notice.

\section{Joint and Combined Operations}

A direct result of the reduction of U.S. forces in the coming decade means that fewer specialized units will be available for tasking. Given the reasonable expectation that the number and complexity of contingency responses will not show a concomitant decrease, the remaining forces will have to produce a greater number of different capabilities with fewer resources, both in size and quantity. As personnel, equipment, and operating budget levels all decrease, the services will of necessity have to combine their capabilities to achieve the same results as in the past. This is the essence of, and the vital necessity for, joint operations. "Every aspect of American military forces must be reassessed to find new and better ways of integrating and employing weapons, people, and technology to focus on strategic - not land, sea, or air -objectives." 12

The end of the Cold War has changed the relationship between the U.S. and its partner nations in various alliances and political efforts around the globe, none perhaps more so than in Europe. The follnwing observation from a senior

12 Schmidt, 55. 
naval officer in that theater highlights a requisite fundamental shift in how the U.S. will have to deal with friendly nations in future crises:

"To maintain influence with our allies, we must shift our relationship from dominant partner to facilitator, moving from the kind of dominance we had during the Cold War to a "central node" role. The notion of force enhancing fits this kind of a shift because it replaces the dependency the F. Iropeans once had on the United States for their survival with a dependency that stems from the utility of working with the US in pursuit of their foreign and security goals. From the national perspective of the US, it also means a different kind of dependency. It means an interdependency based on our ability to facilitate the things the European. want to do with their military forces." 13

In a related fashion, the conduct of operations in Desert Storm and Desert

Shield have demonstrated the need for the U.S. to be able to operate in a coalition environment, where both the political objectives and sensitivities of the coalition partners, and their military capabilities and limitations, have to be taken into account. The ability of U.S. forces to integrate with those of other countries in contingency and littoral operations and to plan and execute combined operations, will be a vital element of the successful employment of U.S. forces in the futurs.

\section{Naval Force Employment}

An earlier U.S. Navy position paper noted that "...naval forces have been the most acceptable form of military presence and response in crisis situations.

13 William Owens, Mediterranean Fleet: A Test-bed for Navy's Future," Armed Eorces Journal International (July 1992), 35. 
They convey calculated ambiguity and calibrated response. At the same time, their presence on the high seas does not irrevocably commit the United States to a given course of action." 14 This flexibility in posıtion and commitment allows national planners greater flexibility in detailing the level and timing of U.S. response to a crisis, which therefore provides more options in managing the level and course of the potential conflict.

\section{Doctrinal Requirements}

"Change is forcing the Navy to play a greater role in Jeterrence and warfare, and doctrine is the only means to meet those challenges effectively." 15

This observation, by a U.S. Air Force officer in his "Call For An Official Naval Doctrine" emphasizes both the need and essential characteristic of that doctrine in the emerging international situation in which naval forces will play a premier role. The vital role that doctrine plays in the effective use of military force derives from the conceptual value of that doctrine to military thought, and its basic relationship to how that thought is channeled into military decision making and planning.

\section{Purpose and Effect}

"Doctrine establishes a particular way of thinking about war and a way of fighting, a philosophy for leading Marines in combat, a mandate for professionalism, and a common language. In short, it establishes the way

\section{OP-08 White Paper, 1.}

15 Schmidt, 46. 
we practice our profession. In this manner, doctrine provides the basis for harmonious actions and mutual understanding." 16

This delineation of the purpose of doctrine, taken from the pre-eminent discussion of warfighting developed by the U.S. Marine Corps, can and should be used by all the services as the touchstone for their own development of professional philosophy. For the purposes of this examination of littoral and contingency doctrine, the key point is the generation of "harmonious actions and mutual understanding". The essential concept of a common understanding embodied in the above statement has to lie at the heart of any system which must respond to a complex situation, on short notice, and with limited resources.

One of the problems with a lack of naval doctrine is that other services don't know how the U.S. Navy views its role in the joint and combined operations of contingency responses, much less within the new regime of littoral warfare. This directly affects how well other military forces can integrate with naval forces, since they cannot understand the (un-articulated) operational philosophy with which we plan and execute our support for those joint or combined operations.

The Joint Chiefs of Staff have defined doctrine as "...an accepted body of professional knowledge...[that] comprises fundamental principles by which military forces or elements thereof guide there actions in support of national

16 U.S. Marine Corps, Warfighting, FMFM-1 (Washington, D.C., 1989), 43. 
objectives." 17 The key point here is that doctrine is the accepted body of knowledge, which can therefore be disseminated and elaborated upon to those who have to understand it. That such basic knowledge of each service, shared among them, is vital for effective integration of their efforts is supremely apparent.

Relationship to Adaptive Planning

The capabilities that military forces provide for utilization in the National Military Strategy are based on the idea of formulating a response to a crisis by using one or more pre-existing sets of military capabilities in a building block fashion to solve the problem at hand. This process is known as Adaptive Planning, where each combatant commander develops his own menu of preplanned options which he can employ to solve problems in his area of responsibility.

"One of the underlying tenets of the strategy is the ability of the combatant commanders to tailor the forces necessary to accomplish their assigned missions from the reservoir of capabilities resident within all of the military services. In effect, our complimentary service capabilities can be seen as tools within the national tool box. Our combatant commanders can use the adaptive planning process to draw the right tools in the precise order needed for the job at hand..." 18

17 U.S. Joint Chiefs of Staff, Basic National Defense Dectrine, Joint Pub 0-1, Proposed Final Draft, 24 July 1990, pg. iv.

${ }^{18}$ Carl E. Mundy, Jr., Expeditionary Forces: A Defining Concept for the Future," Sea Power (April 1992), 52. 
The key concept of the Adaptive Planning process is that the pre-planned options can be executed by the forces which are either available, or will be made available, to carry out those actions. This requires that the capabilities of the forces match the operational and tactical requirements of each of the options, and that the specified elements of these forces can be integrated as expected. The operational doctrine of each service's force elements, detailed to participate in each of these pre-planned options, must therefore serve to ensure that those force elements will be able to integrate as the plans require.

\section{Base Operational Doctrine}

"Since men live upon the land and not upon the sea, great issues between nations at war have always been decided - except in the rarest cases - either by what your army can do against your enemy's territory and national life or else by the fear of what your fleet makes it possible for your army to do." 19

\section{Basis of Naval Operational Doctrine}

The above quote by the famous British theorist of naval power, Sir Julian Corbett, describes the basic characteristic of any naval doctrine which does not have the driving function of the open ocean, Mahanian-type battle; it therefore provides the first basis of any doctrine which encompasses littoral operations. Others include the National-Military Strategy, the precepts of "From The Sea", and the inherent functions and capabilities of naval forces.

19 Geoffrey Till, Cerbett and the 1990s from the Corbett-Richmond Conference, 28-29 September 1992, 13. 
NationaL Military Strategy

The National Military Strategy 20 provides, among others, two foundations applicable to littoral contingency operations: these are Forward Presence and Crisis Response. The forward presence foundation includes such functions as forces stationed overseas, periodic and rotational deployments, combined exercises, and security and humanitarian assistance functions. As a part of forward presence, the regional Commanders in Chief are to conduct training and deployments to "show our commitment to alliances and contribute to regional stability", to "reinforce our ability to participate in coalition and combined warfare", to conduct security assistance operations, to protect U.S. citizens abroad, conduct operations to combat illicit drugs, and to carry out humanitarian assistance efforts. ${ }^{21}$

The crisis response foundation includes the requirements that "U.S. forces must...be able to respond rapidly to deter and, if necessary, to fight unilaterally or as part of a combined effort." 22 The Strategy further notes that in this regard, the U.S. "response might range from a single discriminate strike to the employment of overwhelming force to defeat a regional aggressor. "23

20 Chairman, Joint Chiefs of Staff, The National Military Strategy of the United States, (Washington, D.C., January 1992), $6 \mathrm{ff}$.

21 lbid., 14.

22 lbid., 7.

23 lbid., 12. 


\section{From The Sea}

The naval White Paper "From The Sea" which describes the new concentration on littoral warfare, and which is directly derived from the principles of the National Military Strategy, bases its concept of future operations around the naval expeditionary force. This direction describes that expeditionary force in terms of four essential characteristics: ${ }^{24}$

a. "Swift to respond, on short notice, to crises in distant lands."

b. "Structured to build power from the sea when required by national demands."

c. "Able to sustain support for long-term operations".

d. "Unrestricted by the need for transit or over flight approval from foreign governments in order to enter the scene of action."

\section{Eunction of Navies}

One writer ${ }^{25}$ has proposed a triangular model for the employment of naval forces in the national interest, where a 'trinity of functions' describes the utility of these forces as encompassing three modes of action:

a. The military role is the traditional purpose of naval forces, and encompasses both the maintenance of the balance of power among

\section{O'Keefe, 3.}

25 Ken Booth, Navies and Foreign Policy (London: Croom Helm, 1977), $15 f f$. 
nations, and the projection of force to enhance or predicate national objectives.

b. The diplomatic role is the traditional utility of naval forces, and describes the "management of foreign policy short of the actual employment of force." 26 The enabling abilities which this management provides include negotiation from a position of strength, manipulation of the politico-military situation, and maintenance of national prestige.

c. The policing role is mainly concerned with extending sovereignty over the nation's own maritime frontiers, and includes coast guard responsibilities and economic protections.

Another viewpoint of naval utility is encompassed in Sir James Cable's classic definition of gunboat diplomacy: "the use or threat of limited naval force by a government, short of an act of war, in order to secure an advantage or to avert a loss - either in an international dispute or against foreign nationals within the territory or jurisdiction of their own state." 27

26 Ibid. 16.

27 Sir James Cable, "Gunboat Diplomacy's Future," Proceedings (August 1986), 38. 
Both of these viewpoints illustrate the unique factors of naval force which lend a particular utility to the use of military force in furthering national objectives, especially in response to contingency planning and responses:

a. Naval forces are independently mobile, and thus the level of pressure they apply to a situation is easily modified as circumstances dictate.

b. Naval forces can demonstrate a variable level of threat, appropriate to the situation, yet can be withdrawn with little encumbrance when required.

c. The traditional combination of the military and diplomatic role of naval forces means that potential adversaries view the use of naval forces as representing a significant national interest and willingness to act on the part of the U.S.; however, these forces also avoid the greater threat (implied by air power or armies) of the national exertion of enmity and resolve represented by war.

The first theorist quoted above notes that "The military role forms the basis of the trinity, for the essence of navies is their military character. Actual or latent violence is their currency. It is a navy's ability to threaten and use force which gives meaning to its other modes of action." 28 This becomes ever more significant to any discussion of littoral operations and contingency

28 Booth, 16. 
responses, when considered in light of Corbett's comment at the beginning of this section.

The conclusion one draws is that littoral doctrine must be rooted on and encompass the military nature of naval forces. The ability to generate the requisite level of combat power, and the certain knowledge of potential adversaries that naval forces possess and can employ that power, is the defining characteristic of a littoral doctrine which can meet the range of contingency possibilities.

\section{Required Characteristics}

Based on the foregoing derivation of requirements for contingency operations, including those in the littoral operating environment, the following required doctrinal characteristics are deduced:

The doctrine must be based on the principle of contingency responsiveness. Littoral operations are not a new environment for U.S. naval forces; neither is the necessity to respond to a rapidly developing situation. The doctrine must acknowledge that the actual employment of naval forces will be in a crisis based, rapidly developing scenario where already extant skills and resources will have to be utilized.

The doctrine must incorporate the principles of adaptive planning, and provide the basic capabilities to meet all pre-planned military options that the regional $\mathrm{CinC}$ will expect are available to him. 
The doctrine must be standardized among all deployed forces and units, regardless of their location and original tasking. The variety of possible crises and locations demands that the reduced number of available forces be able to respond anywhere they can reach in the time available.

Flexibility must be a key characteristic of its operations and available response techniques. This will enhance the effectiveness of pre-planned responses to the actual situation, and maintain the flexibility needed by the national authorities. Naval forces have been, and must be, able to heighten or reduce the apparent threat as the crisis develops and changes.

The doctrine must incorporate as a basic assumption that operations will be conducted jointly among all the U.S. military services, and may very well include combined operations with other nations' forces. This demands a simplicity and rigor in the structure and methods of command and control, communications procedures, and employment of forces to prevent mutual interference.

The doctrine must provide a seamless welding of units available at or near the scene of a crisis, and must allow for the joining of additional forces, as they become available, without disruption to the operations in progress. This includes incorporating additional levels of command structure, and shifting command functions as required.

The doctrine must encompass the ability to project force, or varying levels of the threat of force, up to, over, and on the land; further, the doctrine must 
encompass the ability to maintain and support this threat or use of force from the unhampered range of the sea.

\section{Development}

The development of a doctrine of naval force employment in littoral contingency operations must be centered on incorporating the characteristics previously developed, and must be structured to encompass both the requirements of the National Military Strategy and the pre-planned options of the Adaptive Planning concept. It will be necessary for those developing this doctrine to define the base operational mission capabilities, derived from the preplanned options, that naval forces must be able to carry out. When the planners have defined the base operational tasks, the requirements of those tasks will allow determination of the basic force structures, capabilities, and skills that must be included in the doctrine.

\section{Conclusions}

This paper has developed the essential characteristics required of a naval doctrine in littoral operations, noting that these hold true generally acioss the range of contingency operations. The flexibility of naval forces, their historical access and utility, and the apparent nature of their application in the foreseeable future provide one set of requirements for such a doctrine. The numerical reductions in those forces, along with the changing international political landscape of cooperation among nations, dictate a different set of requirements. The melding of these varying and, at times conflicting, planning and operational 
limitations produces the need for, and a description of, a finite, coherent, and usefully employable doctrine for littoral contingency operations.

"Such a doctrine must become the fighting foundation for every sailor, airman, and soldier connected with American maritime power. It should be the basis for how the Navy plans to fight (when and if it does), how it will train, and how it will structure and build future forces and equipment. It must be realistic, understandable, and useful. Most importantly, it must become the core of Navy combat philosophy, "acting as a unifying though process without producing predictable thoughts." 29

29 Schmidt, 46. The quote at the end of this passage is from Scott R. Moore, "Bridging the Doctrinal Gap," Marine Corps Gazette (April 1988), 49. 


\section{Bibliography}

\section{Primary References}

Anderson, Gary W. "Beyond Mahan: Naval Doctrine in the Post-Cold War World." Marine Corps Gazette (June 1992): 38-41.

Aspin, Les. "With The Soviets and Cold War Gone, What is the Future for US Forces?" The Officer (November 1992): 21-26.

Barnett, Roger W. "Regional Conflict: Requires Naval Forces." Proceedings (June 1992): 28-33.

Barnett, Roger W. "U.S. Strategy, Freedom of the Seas, Sovereignty and Crisis Management." Strategic Review (Winter 1992): 32-41.

Blechman, Barry M. and Stephen S. Kaplan. The Use of Armed Forces as a Political Instrument. Washington, D.C.: Brookings Institution, 1977.

Blechman, Barry M.. "Global Power Projection - The U.S. Approach," In Projection of Power: Perspectives, Perceptions and Problems, edited by Uri Ra'anan, Robert L. Pfaltzgraff, Jr. and Geoffrey Kemp. Boston: The Fletcher School of Law and Diplomacy of Tufts University, 1992.

Booth, Ken. Navies and Foreign Policy. London: Croom Helm, 1977.

Cable, Sir James. "Gunboat Diplomacy's Future," Proceedings (August 1986): 37-41.

Chairman, Joint Chiefs of Staff. The National Military Strategy of the United States. Washington, D.C., January 1992.

Department of the Navy. The Necessity for Naval Power in the 1990s, OP-08 White Paper. Washington, D.C., 1989.

Donovan, James A. "New Concepts and New Doctrine." Marine Corps Gazette (June 1992): 42-44.

Fitz-Simmons, Daniel W. "The Role of the Marine Corps Over the Next Decade." Naval War College Review (Winter 1993): 109-112. 
Garrett, H. Lawrence, III, Frank B. Kelso II and A. M. Gray. "The Way Ahead.," Proceedings (April 1991): 36-47.

Larsen, r'iarles R. "National Interests and Naval Forces in the 1990s." Naval ¿var College Review (Winter 1990): 9-19.

Linn, Thomas C. "Naval Forces in the Post-Cold War Era." Strategic Review (Fall 1992): 18-23.

Mahnken, Thomas G. "Planning U.S. Forces for the Twenty-First Century." Strategic Review (Fall 1992): 9-17.

Miller, Paul David. "Doing the Job With a Smaller Fleet." Proceedings (April 1992), 54-59.

Montenegro, Guillermo J. "Alternative Naval Strategies." Naval War College Review (Spring 1992): 51-58.

Moore, R. Scott. "Rethinking the MAGTF." Marine Corps Gazette (June 1992): 20-24.

Mundy, Carl E., Jr. "Redefining the Marine Corps' Strategic Concept." Proceedings (May 1992): 66-70.

Mundy, Carl E., Jr., Expeditionary Forces: A Defining Concept for the Future," Sea Power (April 1992): 43-52.

Newman, Micajah W. "Navy Operational Doctrine." Operations Research Paper, Naval War College, 1992.

O'Keefe, Sean, Frank B. Kelso II, and Carl E. Mundy, Jr., ...From the Sea, Navy and Marine Corps White Paper. Department of the Navy, Washington, D.C., September 1992.

Owens, William. Mediterranean Fleet: A Test-bed for Navy's Future," Armed Eorces Journal International (July 1992): 32-35.

Powell, Colin L. "The Eisenhower Centenary Lecture: Military Realities and Future Security Prospects." Royal United Services Institution Journal (Spring 1991): 17-21. 
Schmidt, Stephen D. "A Call for an Official Naval Doctrine." Naval War College Review (Winter 1993): 45-58

Till, Geoffrey. Corbett and the 1990s from th- Corbett-Richmond Conference, 28-29 September 1992. Naval War College, 1992.

Toti, William J. "Sea-Air-Land Battle Doctrine." Proceedings (September 1992): 70-74.

U.S. Joint Chiefs of Staff, Basic National Defense Doctrine, loint Pub 0-1, Proposed Final Draft, 24 July 1990.

U.S. Marine Corps, Corps Operations, FM 100-15. Washington, D.C., 1988.

U.S. Marine Corps, Warfighting, FMFM-1. Washington, D.C., 1989.

\section{Ancillary References}

Fallon, Michael O. "Gator Aid: A Solution to the Amphibious Lift Probiem." Marine Corps Gazette (April 1992): 71-73.

Franks, Frederick M., Jr. and Gary B. Griffin. "The Army's View of Joint." Proceedings (May 1993): 54-60.

Kelso, Frank B. II. "Charting a Course for the Future." Sea Power (April 1991): 13-20.

Liddell-Hart, B. H. "The Value of Amphibious Flexibility and Forces." Journal of the Roval United Services Institution CV:620 (November 1960): 483-492.

McNulty, James F. "Naval Presence - The Misunderstood Mission." Naval War College Review (September-October 1974): 21-31.

Munson, Curtis A. and Dwight Lyons. Who Fights the MAGTF." Marine Corps Gazette (June 1992): 28-31.

Phillips-Beaudan, Eric. "At Sea With The New World Order." Defense and Diplomacy 9:9-10 (October/November 1991): 51-54.

Powell, Colin L. "Dealing With The Changes." Proceedings (July 1992): 11-15. 


\section{Pugh, Paul F. "Operational Art and Amphibious Warfare." Marine Corps}

Gazette (July 1991): 81-85.

Tailyour, R. S. "The Future of Amphibious Warfare." Royal United Services Institution Journal (Spring 1991): 33-37. 